\title{
Neurophysiological and clinical aspects of nerve communications of the upper and lower extremities
}

\author{
Osman Sinanović ${ }^{1,2,3}$, Sanela Zukić ${ }^{1}$ \\ Medical Faculty, University of Tuzla, 75000 Tuzla, \\ 2 Sarajevo Medical School, University of Sarajevo School of Science and Technology, \\ 3 Academy of Medical Sciences of Bosnia and Herzegovina, 71000 Sarajevo, Bosnia and Herzegovina
}

OPEN ACCESS

\section{Correspondence:}

Osman Sinanović osman.sinanovic1@gmail.com orcid.org/0000-0001-8957-7284

This article was submitted to RAD CASA - Medical Sciences as the original article

Conflict of Interest Statement: The authors declare that the research was conducted in the absence of any commercial or financial relationships that could be construed as a potential conflict of interest.

Received: 22 November 2020 Accepted: 4 December 2020 Published: 28 December 2020

Citation:

Sinanović O, Zukić S. Neurophysiological and clinical aspects of nerve of the upper and lower extremities

RAD CASA - Medica 544=52-53 (2020): 88-97 DOI: https://dx.doi.org/10.21857/ m8vqrtq789

Copyright (C) 2020 Sinanović O, Zukić S. This is an open-access article distributed under the terms of the reative Commons Attribution License

(CC BY). The use, distribution or reproduction in other forums is permitted, provided the original author(s) and the copyright owners(s) are credited and that the original publication in this journal is cited, in accordance whit accepted adacemic practice. No

use, distribution or reproduction is permitted which does not comply with these terms.

\section{SUMMARY}

Introduction: Anomalous innervations of the extremities are common and influence the interpretation of electrophysiologic studies in normal subjects and those with peripheral nerve lesions. The aim of this study was to describe the most common innervation anomalies in upper and lower extremities and to point out their clinical repercussions. Methods: Article has an analytical character and review of literature, including some personal articles. Results and Discussion: Double innervation and communications among nerves are causes of anomalies of innervation of the skin and muscles. The fact of communications of fibers among nerves is better called "nerve communication" than "nerve anastomosis". Anomalous innervations of the upper and lower extremities are, therefore, common and influence on the interpretation of neurophysiological parameters during electromyoneurography. Namely, in the course of an electrodiagnostic investigation of a peripheral nerve lesion, the examiner may be confronted with unexpected findings in contradiction with the clinical picture. In this review, a description is given of the most common innervation anomalies in upper and lower extremities: median to ulnar nerve communication (Martin-Gruber anastomosis); ulnar to median nerve communication (Marinacci anastomosis/MA); variations in the innervation of intrinsic muscles of the hand (Riche-Cannieu anastomosis; Berrettini anastomosis); accessory deep peroneal nerve; and tibial to peroneal nerve communication. Conclusion: As anomalous innervations of the extremities are common and influence the interpretation of electrophysiological studies in normal subjests and those with peripheral nerve lesions, detailed anatomical knowledge is essential for accurate interpretation of physical examination, electrophysiological findings, diagnosis, prognosis and reducing the risk of iatrogenic injuries during surgical procedures. If these variations are not given due regard, errors and other consequences will be inevitable.

KEYWORDS: Variation in innervation - Upper and lower extremities - Electromyoneurography Diagnosis - Prognosis

\section{SAŽETAK}

NEUROFIZIOLOŠKI I KLINIČKI ASPEKTI KOMUNUKACIJE IZMEĐU ŽIVACA NA GORNJIM I DONJIM EKSTREMITETIMA Anatomske varijacije u inervaciji na ekstremitetima su česte i utječu na tumačenje elektrofizioloških analiza, kako u zdravih ispitianika tako isto i onih s lezijama perifernih živaca. Cilj ovog članka je bio opisati najčešće anatomske varijacije u inervaciji gornjih i donjih ekstremiteta i ukazati na njihov klinički značaj. Metode: Članak ima analitički karakter i pregled literature, uključujući neke osobne članke. Rezultati i Diskusija: Dvostruke inervacije i komunikacije između živaca uzrokuju anom- 
alne inervacije kože i mišićia. Terminološki, komunikaciju vlakana među živicima bolje je nazvati „komunikacija među živcima“" nego živčana anastomoza“. Anomalne inervacije na gornjim i donjim ekstremitetima su, dakle česte i utječu na tumačenje neurofizioloških parametara u tijeku elektormioneurografije. Naime, tijekom elektrodijagnostičkog ispitivanja lezije perifernog živca, ispitivač se može suočiti s neočekivanim nalazima koji mogu biti u suprotnosti s prezentiranom kliničkom slikom. U ovom preglednom članku dan je opis najčešćih anomalija u inervaciji gornjih i donjih ekstremiteta: komunikacija između medijanusa i ulnarisa (Martin-Gruberova anastomoza); komunikacija koja ide od ulnarnog prema medijalnom živcu (Marinacci-jeva anastomoza); varijacija u inervaciji intrizičkih mišića šake (Riche-Cannieu-ova anastomoza; Berrettini-jeva anastomoza); akcesorni duboki peronelani živac i komunikacija između tibijalnog i peronelanog živca. Zaključak: Kako su anatomske varijacije u inervaciji ekstremiteta česte i utječu na interpretaciju elektrofizioloških analiza, kako u zdravih subjekata, tako isto i u onih s lezijma perifernih živaca, detaljna anatomska znanja su ključna za točnu interpretaciju fizikalnog pregleda, elektrofizioloških anliza, dijagnostičkog zaključka, progonoze i smanjenja rizika od nastanka jatrogenog oštećenja tijekom kirurških zahvata. Ako se ove varijacije ne uzmu u obzir, pogreške i druge posljedice bit će neizbježne.

KLJUČNE RIJEČI: Varijacije u inervaciji - Gornji i donji ekstremiteti - Elektormioneurografija Dijagnoza - Progonoza

\section{INTRODUCTION}

Double innervation, abnormal innervation and communications among nerves are causes of anomalies of innervation. The fact of communications of fibers among nerves is better called "nerve communication" than "nerve anastomosis". The different anatomical anomalies of peripheral nerves occur with various frequencies in the population ${ }^{1-2}$. The most widely recognized are Martin-Gruber anastomosis (MGA), accessory deep peroneal nerve (ADPN), and complete innervations of the intrinsic hand muscles by the ulnar nerve ("all ulnar hand").

Anomalous innervations of the upper and lower extremities are common and influence the interpretation of neurophysiological studies in normal subjects and clinical features of those with peripheral nerve lesions ${ }^{3}$. Namely, in the course of an electrodiagnostic investigation of a peripheral nerve lesion, the examiner may be confronted with unexpected findings in contradiction with the clinical picture. Awareness of such anomalies may be important in order to avoid misdiagnoses during electrophysiological study, such as a conduction block involving the ulnar nerve or carpal tunnel syndrome or axonal lesion of the peroneal nerve ${ }^{1-6}$.

On the upper limb, it was described several communicating branches between median and ulnar nerve. Anastomosis in which the branch anastomotic originates proximally in the median nerve and unites distally in the ulnar nerve is known as median - ulnar anastomosis type or Martin-Gruber anastomosis (MGA). Martin, a Swedish anatomist in 1763. was the first one to consider the possibility of connection between the fascicles of the median to ulnar nerves in the forearm ${ }^{7}$, and than in 1870. Gruber dissected 250 forearms and found 38 connections $(15.2 \%)^{8}$.
Anatomic studies have estimated its frequency from 10.5-44\% ${ }^{4}$, and electrophysiological studies demonstrating the connection in $14-34 \%{ }^{9}$. Reversed Martin-Gruber anastomosis, ulnar - to - median nerve anastomosis, known as Marinacci comunication (MA), rises from ulnar nerve, and join the median nerve, also in the forearm. Marinacci (in 1964) first reported patient who, following trauma of the median nerve, at the forearm, had preservation of median nerve innervated hand muscle despite denervation of forearm flexors ${ }^{10-11}$. Occurence frequency for MA was reported as $1.3 \%$, by Kimura et al. ${ }^{12}, 4 \%$ by Sundaram et al. ${ }^{13}$ but in recent meta-analysis by Roy et al. ${ }^{15}$ the overall pooled prevalence of this anastomosis was $0.7 \%$, and for MGA the overall pooled prevalence was $19.5 \%$. This study included a total 58 articles.

On the lower limb the most widely recognized is accessory deep peroneal nerve $(\mathrm{ADPN})^{16}$. ADPN was reported initially by Ruge in 1878 , and the first anatomical description was provided by Bryce (1891, 1901). Winckler published in 1934 a more detailed analysis of this nerve and reported a more frequent occurrence in man (7 of 19 legs) ${ }^{17}$. From the late 1960s, this anomalous variation has been reported to occur in as many as $28 \%$ of people ${ }^{18-19}$. This anomaly has an autosomal dominant pattern of inheritance in $\operatorname{man}^{19-21}$.

\section{Martin-Gruber AnAstomosis}

The anatomy of the upper limbs is very complex. In addition to the complexity of the format of the brachial plexus and the existence of specific anatomical zones such as the ulnar, carpal and Guyon canal, anomalous nerve branches can be found. These may form anastomoses in particular sites that have clinical and functional importance ${ }^{22}$. 


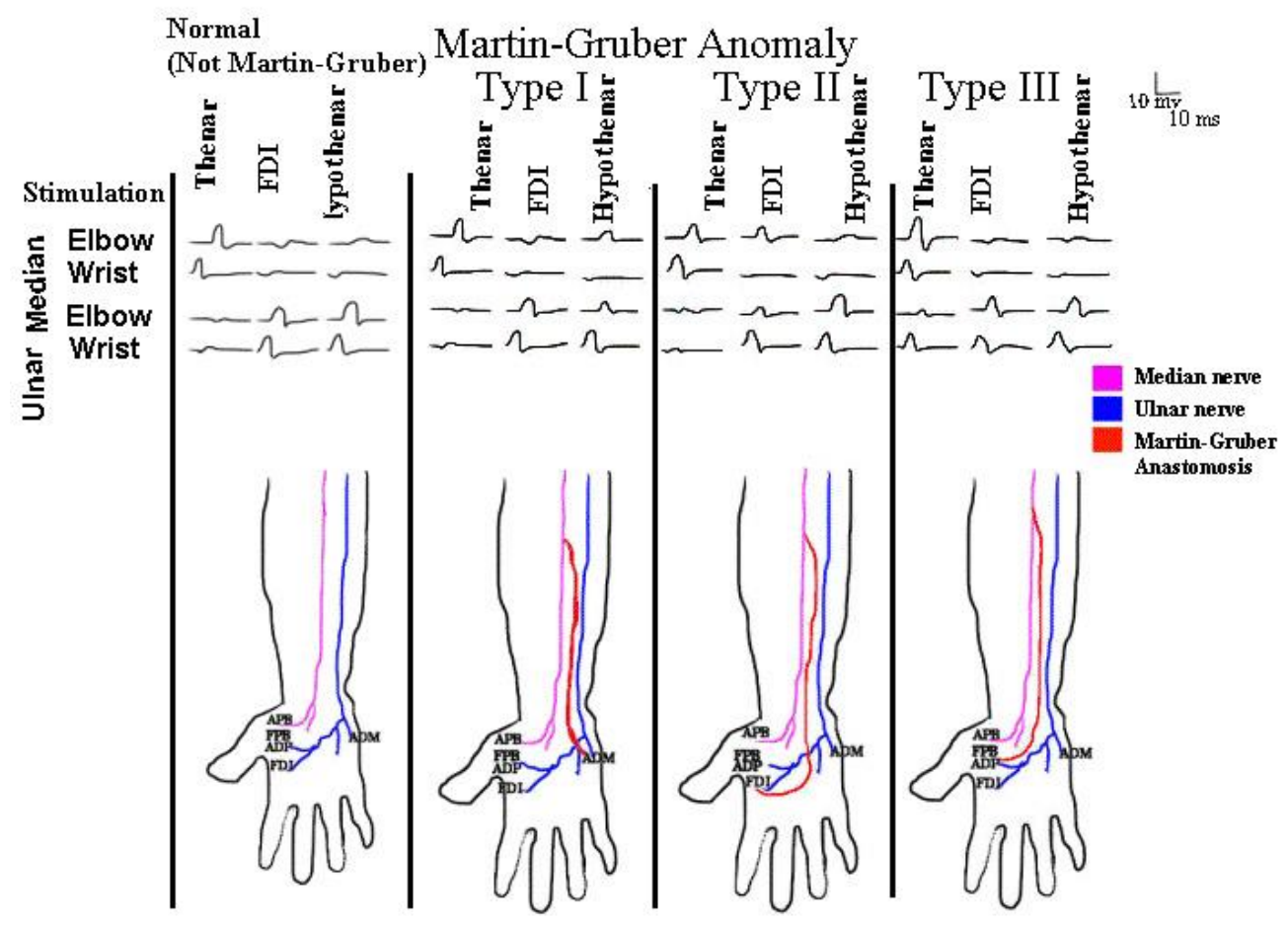

Figure 1. Types of nerve communications (anatomical variations) between the median and ulnar nerve

The innervation pattern that is most often in relation to the intrinsic muscles that act in relation to fine movements of the hand is that the opposing short abductor muscle, the superficial portion of the short flexor muscle and the first and second lumbrical muscles receive innervation from the median nerve. The deep portion of the short flexor muscle, the adductor muscle of the thumb, the muscles of the hypothenar region, the dorsal and palmar interosseous muscles and the fourth and fifth lumbrical muscles are innervated by the ulnar nerve ${ }^{22}$. But, as we already mantained, the great variety of the different anatomical anomalies of peripheral nerves occur with various frequencies in the population ${ }^{6}$. Clinically, variations of the innervation of these small muscles are very important, in that even if the median or ulnar nerve is completely damaged, some of these muscles may not necessarily be paralyzed. This could lead to the wrong conclusion that the nerve had not become damaged $^{3,22-23}$.

Reports on clinical cases have often suggested that double innervation of these muscles exists ${ }^{5,11}$. Nerve communication (anatomical variations) between the median and ulnar nerves may occur in the forearm, usually in the proximal third of the forearm (Martin-Gruber anastomosis), between the thenar motor branch of the median nerve and the deep motor branch of the ulnar nerve in the palm of the hand (Cannieu and Riché anastomosis) or between the sensory branches of the two nerves, also in the palm of the hand (Berretini anastomosis or superficial sensory communicating branch). Thus, the variety of clinical conditions observed in cases of isolated lesions of the median and ulnar nerves disagrees with the classical innervation pattern of these muscles that is suggested by classical anatomical studies.
Furthermore, better knowledge of the anatomical variations in the innervation of these muscles is important with regard to diagnosing nerve injuries ${ }^{3,6,11,23}$.

A variety of anomalous interconnections exist between the median and ulnar nerves in the forearm and hand. Some reports in the literature have differentiated three types of Martin-Gruber communication. In types I and II, anomalous innervation of the abductor muscles of the little finger and the first dorsal interosseous muscle, respectively, are observed. In type III, there is anomalous innervation of the short abductor of the thumb. In types I and II, nerve fascicles head from the median to the ulnar nerve, while in type III (Cannieu and Riché anastomosis) they head from the ulnar to the median ${ }^{22-24}$ (Figure 1).Furthermore, we can also talk about the four major types of anomalous interconnections between the median and ulnar nerves in the forearm and hand: Martin-Gruber anastomosis (MGA), Marinacci anastomosis (MA), Riche-Cannieu anastomosis (RCA), and Berrettini anastomosis (BA), with the former two occurring in the forearm and the latter two arising in the hand ${ }^{25}$.

MGA is considered to follow an autosomal dominant pattern of inheritance ${ }^{17,26-27}$ and has been linked to Trisomy 21 with bilateral presentation ${ }^{28}$. However, in already mentioned recent meta-analysis by Roy et al. ${ }^{15}$ MGA was more commonly found unilaterally $(66.8 \%)$, on the right side $(15.7 \%)$, following an oblique course $(84.8 \%)$, and originating from the anterior interosseous nerve with a prevalence of $57.6 \%$. It is probably the most well known of the anastomotic anomalies that occur at various levels between the median and ulnar nerves $5,11,15$ (Figure 2). 
The electrophysiological recognition of these anomalies and the manner in which they affect the interpretation of electrodiagnostic studies in various conditions is very important ${ }^{3}$. It is formed by motor axons from the median nerve or its branch anterior interosseous nerve that cross in the upper forearm to join the ulnar nerve. Anatomic studies have estimated its frequency from $10.5-44 \%{ }^{29}$, and electrophysiological studies demonstrating the connection in $14-34 \%^{30-31}$. It may be unilateral or often bilateral ${ }^{26}$. Roy et al. ${ }^{14}$ showed that MGA is more commonly unilateral and on the right side, in agreement with other studies ${ }^{32-34}$. This anastomosis predominantly consists of motor axons, with rare sensory contribution, which may follow different distribution ${ }^{35}$. Simonetti ${ }^{36}$ wrote that although anatomical studies have shown that a crossover of sensory fibers is not rare in forearm Martin-Gruber median-ulnar anastomosis; however it has been electrophysiologically described only in rare subjects.According to the recent anatomical study of Diz-Díaz et al. ${ }^{37}$ almost a third of specimens were found to have MGA connections composed of motor and sensory fibers. In one our study we have demostrated the high incidence of sensory fibers $(30.9 \%$ of 113 subject with motor form of MGA) ${ }^{38}$.

While MGA is most frequently associated with the ulnar artery, it is important to note that it has also been related to the anterior ulnar recurrent artery. Awareness of this variation during open reduction and internal fixation of a radius/ulnar shaft fracture may be significant in minimizing iatrogenic damage ${ }^{14,24,28}$.

The clinical implications of MGA are incomprehensible. Riechers et al. ${ }^{39}$ quote this anastomosis as the main factor causing or inducing complications during surgical procedures. In addition to cases involving the anterior ulnar recurrent artery, iatrogenic damage is possible in the management of ulnar artery reconstruction, wrist drop, and ulnar nerve transposition ${ }^{14,40-41}$.

Complication of diagnosis of carpal tunnel syndrome, cubital tunnel syndrome, peripheral lesions, and neuropathies may also result in the presence of MGA. For example, in the case of carpal tunnel syndrome, there may be partial or total sparing of thenar muscles, atypical as well as unusual findings insensitive innervations of the fingers and evoked muscle potentials ${ }^{20}$ $24,40,42-43$. Conversely, a patient may present with symptoms of carpal tunnel syndrome, but show negative findings with regard to Tinel and Phalen tests, due to ulnar nerve compression at the elbow ${ }^{44}$.

\section{MARINACCI ANASTOMOSIS}

The ulnar to median nerve anastomosis (Marinacci anastomosis/ $\mathrm{MA}$ ), also known as reverse MGA, in the forearm is a rare occurance $^{11}$. MA, like MGA, is mainly comprised of motor fibers, with few accounts of afferents only ${ }^{45}$. Resende et al. ${ }^{46}$ suspected on this diagnosis on electrophysiological study when CMAP of the abductor pollicis brevis muscle obtained by maximal stimulation of the median nerve at the elbow, was lower than obtained at the wrist. The diagnosis was confirmed by stimulation of the ulnar nerve at the elbow, which evoked a CMAP of the same muscle with a clear negative initial deflection. Presence of MA should be suspected if ulnar nerve stimulation, during electroneurography, at the elbow yields compaund muscle action CMAPs with larger amplitudes than with stimulation at the wrist

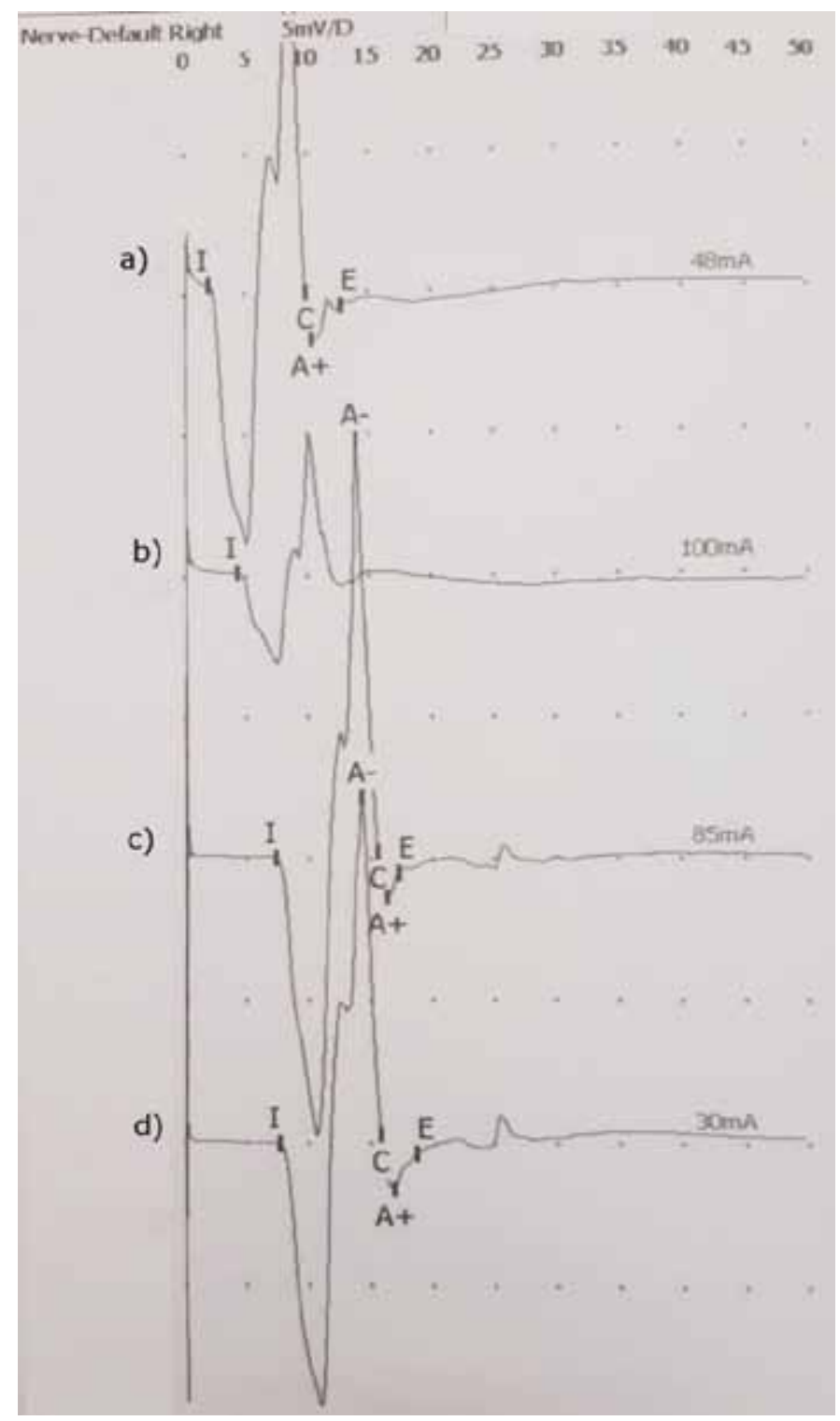

Figure 2. Martin - Gruber anastomosis by electrodiagnostical investigation or electroneurography - plurisegmental analysis of ulnar nerve

(a) Compound muscle action potential (CMAP) recorded by stimulation of ulnar nerve at wrist

(b) CMAP recorded by stimulation of ulnar nerve below elbow;

(c) CMAP recorded by stimulation of ulnar nerve above elbow;

(d) CMAP recorded by stimulation of median nerve at elbow 
${ }^{24}$. Knowledge of this anosotmosis can prevent interpretation of changes over the median nerve as neuropraxia (24)

Knowledge of the anastomosis between these nerves is important for clinical practice. Brandsma et al. ${ }^{47}$ reported that the clinical importance of this anastomosis is that an isolated ulnar nerve lesion at the elbow may produce an unusual pattern of intrinsic muscle paralysis. On the other side, the presence of MGA causing a decline in ulnar CMAP amplitude across the elbow segment, and could mimic a partial conduction block, which would suggest ulnar neuropathy at the elbow ${ }^{48}$. Dogan et al. ${ }^{49}$ described the case of a patient with a condition of compressive neuropathy of the ulnar nerve who presented altered sensitivity in the ring finger and little finger, but with atrophy of the short abductor muscle of the thumb. They attributed this finding to an anomaly of innervation of the short abductor. Scelsa ${ }^{50}$ reported an ulnar-median anastomosis (MA) in the forearm in a patient with clinical and electrophysiological evidence of ulnar neuropathy at the elbow and unexpected fibrillations in the abductor pollicis brevis muscle. So, unexpected finding of these fibrillations should raise the possibility of the MA. Therefore, the clinical implications of MA are important, and a lack of attention to the changes in amplitude in the CMAPs upon proximal and distal ulnar nerve stimulation can lead to changes over the median nerve being interpreted as neuropraxia ${ }^{24,51}$. Median nerve injuries at the elbow may not result in clinically significant effects on the thenar muscles, and ulnar nerve injuries at the elbow may be accompained by denervation changes over median-innervated thenar muscles ${ }^{24,51}$.

\section{THE ACCESSORY DEEP PERONEAL NERVE}

According to standard textbooks of anatomy the peroneal nerve is derivate from the L4-S1 nerve roots, which travel from the lumbosacral plexus and eventually the sciatic nerve. Within the sciatic nerve, the fibers forming the peroneal nerve run separately from those that become the tibial nerve. More distally, the sciatic nerve bifurcates above the popliteal fosse into the common peroneal and tibial nerves. The common peroneal nerve first gives rise to the lateral cutaneous nerve of the knee, and divides into the deep and superficial peroneal nerves.

The deep peroneal nerve innervates the peroneus tertius muscle and the dorsiflexors of the ankle and toes, including the tibialis anterior muscle, extensor digitorum longus and extensor hallucis longus, and extensor digitorum brevis ${ }^{2,52-53}$.

The accessory deep peroneal nerve has been regarded as an anomalous nerve derived from the superficial peroneal nerve or its branch and supplies motor innervations for extensor digitorum brevis (EDB) and sensory innervations for the lateral part of the ankle and foot regions ${ }^{54}$. ADPN arises from the superficial peroneal nerve on the lateral aspects of the leg, descends along the posterior border of the peroneus brevis muscle near to the Achilles tendon and sural nerve and winds around the lateral malleolus (Figure 3) 5,55 .

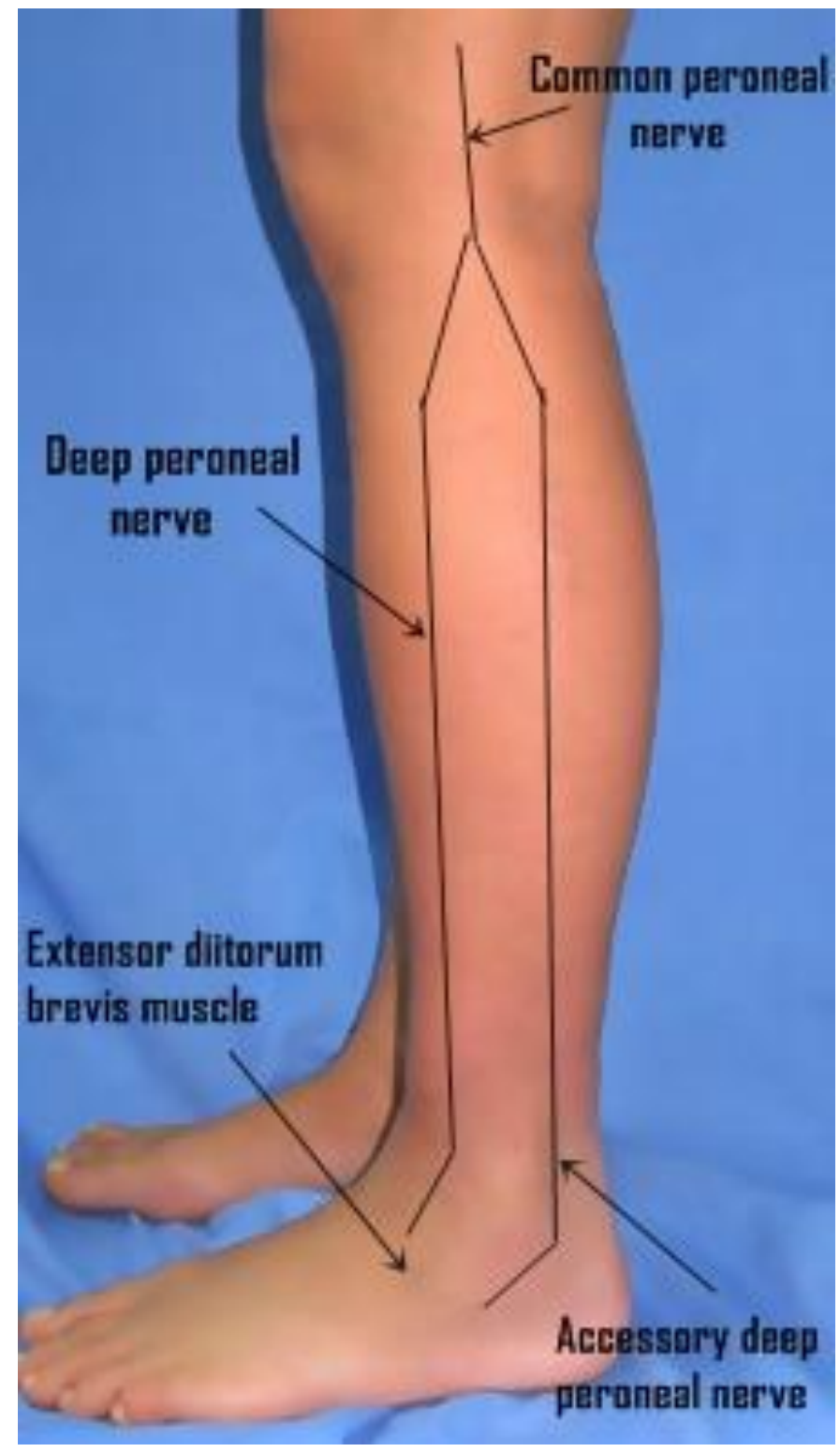

Figure 3. The accessory deep peroneal nerve

ADPN was reported initially by Ruge in 1878 , and the first anatomical description was provided by Bryce (1891, 1901). Winckler published in 1934 a more detailed analysis of this nerve and reported a more frequent occurrence in man (7 of 19 legs) ${ }^{54}$. From the late 1960 s, this anomalous variation has been reported to occur in as many as $28 \%$ of people ${ }^{54-56}$. This anomaly has an autosomal dominant pattern of inheritance in $\operatorname{man}^{20,57}$. The EDB is usually innervated exclusively by the deep peroneal nerve, however, in some cases, one or both of the EDB muscles are innervated by the ADPN nerve (partially or exclusively), and could be detected by nerve conduction studies (Figure 4 i 5) 53, 57 . It was reported that $\mathrm{ADPN}$ was present in $12-35 \%$ of the popula- 


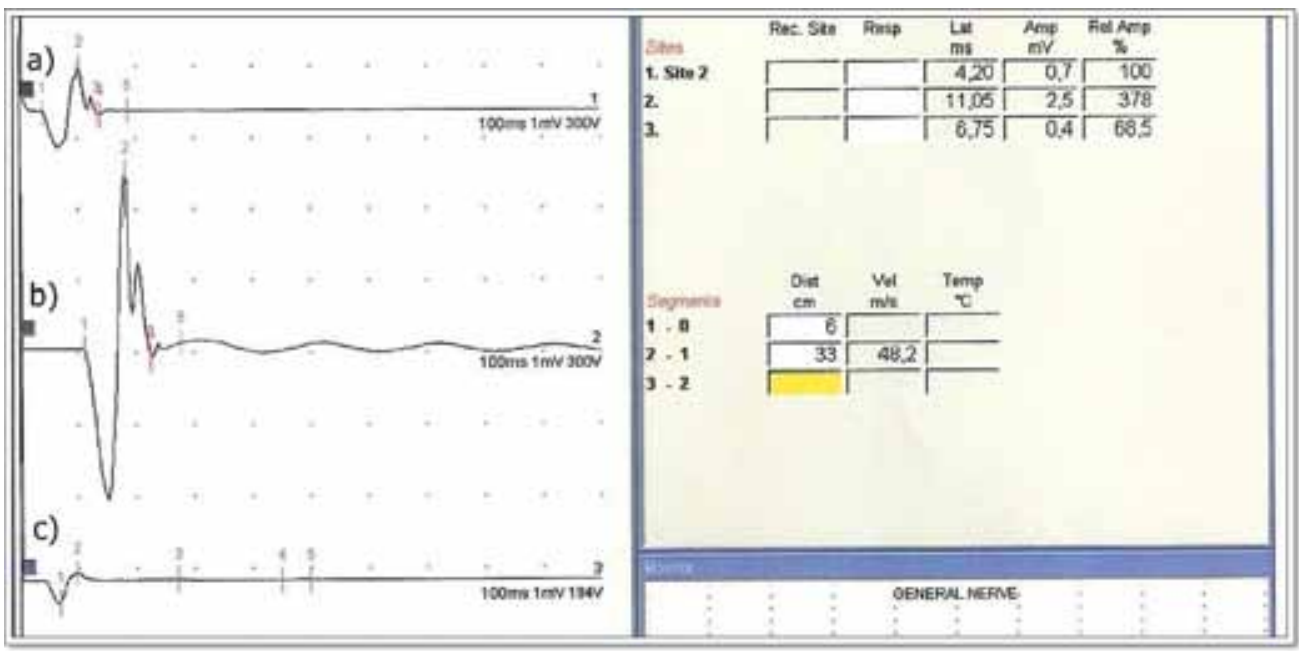

a) action potential evoked when stimulating the deep peroneal nerve at the ankle;

b) action potential evoked when stimulating the common peroneal at the knee;

c) action potential evoked when stimulating the accessory deep peroneal nerve

Figure 4. Muscle extensor digitorum brevis partially innervated by accessory deep peroneal nerve

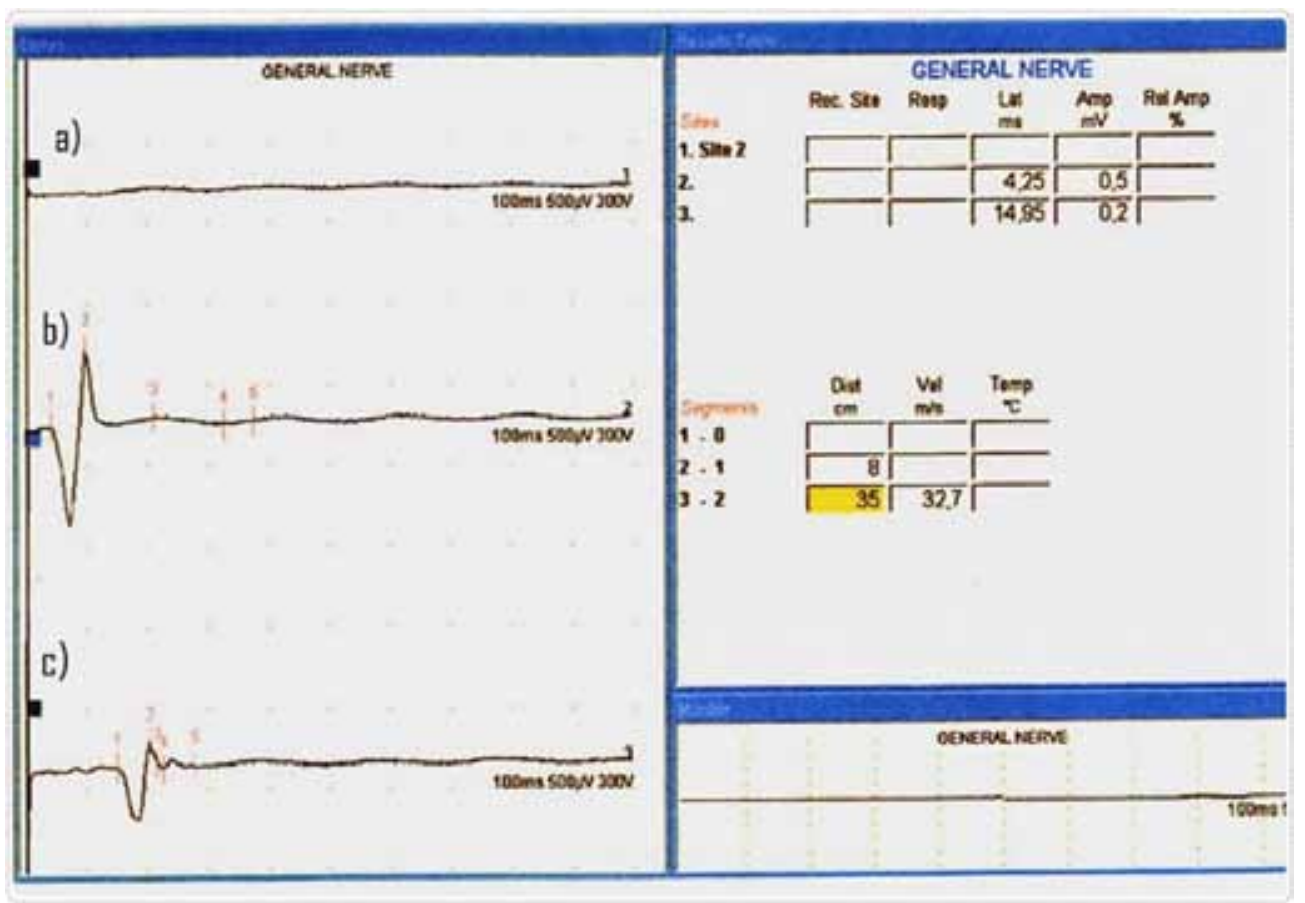

a) no action potential when stimulating the deep peroneal nerve at the ankle; b) action potential evoked when stimulating the common peroneal at the knee; c) action potential evoked when stimulating the accessory deep peroneal nerve

Figure 5. Muscle extensor digitorum brevis exclusively innervated by accessory deep peroneal nerve 
tion ${ }^{58}$. It was found that there is a wide variation of prevalence of ADPN among different studies ${ }^{58-63}$. One a meta-analysis study assessed the overall pooled ADPN prevalence of $18.8 \%$, the electrophysiological pooled ADPN prevalence of $13.6 \%$, and the anatomical pooled prevalence of $39.3 \%{ }^{63}$. This could be explained by the differences between studies regarding the studied population and the techniques used in the assessment of ADPN, whether anatomical or electrophysiological studies ${ }^{57,58,63}$.

The ADPN has more than one clinical importance ${ }^{54,57,58,63-64}$. Studying the ADPN can complicate the clinical picture and disturb the interpretation of the electrophysiological studies of common peroneal, deep peroneal, and superficial peroneal nerves lesions and injuries, as well as, ADPN neuropathy ${ }^{54,57}$. Namely, superficial peroneal nerve and its branches (including ADPN) are risk for iatrogenic damage while performing arthroscopy, local anesthetic block, surgical approach to the fibula, open reduction and internal fixation of lateral malleolar fractures, application of external fixators, elevation of a fasciocutaneous or fibular flaps for grafting, surgical decompression of neurovascular structures, or miscellaneous surgery on leg, foot and ankle ${ }^{57,59}$.

\section{TIBIAL-TO-PERONEAL NERVE COMMUNICATION}

Phillips and Morgan in $1993^{66}$ described the findings in a case of tibial-peroneal nerve communication on the basis of intraoperative nerve conduction studies. Stimulation of the tibia1 nerve produced a contraction from the peroneus longus muscle and a nerve action potential in the distal peroneal nerve ${ }^{5,66}$. A prior tibial-peroneal communication was reported but no details given 5,67 . Linden and Berlit ${ }^{68}$ this nerve communications named ,all tibial foot", and this raer anomalous innervation were described in several other case reports ${ }^{69-71}$. Yamashita et al. ${ }^{71}$ emphasized that this communication between the tibial and deep peroenela nerves include sensory fibers. Swerdloff and Stewart in their recently paper $^{72}$ reported frequency of this anomalous as $11 \%$ ( 8 cases out of 72 subjects), and communication was present in both legs in half of the subjects.

\section{CONCLUSION}

Anomalous innervations of the upper and lower extremities are common and influence the interpretation of neurophysiological studies in normal subjects and clinical features of those with peripheral nerve lesions. Namely, in the course of an electrodiagnostic investigation of a peripheral nerve lesion, the examiner may be confronted with unexpected findings in contradiction with the clinical picture. The most common innervation anomalies in upper and lower extremities are: median to ulnar nerve communication (Martin-Gruber anastomosis/MGA) and accessory deep peroneal nerve (ADPN), then ulnar to median nerve communication (Marinacci anastomosis/MA); variations in the innervation of intrinsic muscles of the hand (RicheCannieu anastomosis/RCA; Berrettini anastomosis) and tibial to peroneal nerve communication (TP).

As anomalous innervations of the extremities are common and influence the interpretation of electrophysiological studies in normal subjects and those with peripheral nerve lesions, detailed anatomical knowledge is essential for accurate interpretation of physical examination, electrophysiological findings, diagnosis, prognosis and reducing the risk of iatrogenic injuries during surgical procedures. If these variations are not given enough attention, errors and other consequences will be inevitable. 


\section{LITERATURE:}

1. Brzović Z, Žagar M, Jurenić D, Sinanović O. Physiological variation in the innervation of flexor carpi ulnaris muscle. Neurologija. 1987; 36: 77-84.

2. Sinanović O, Pirić N. Musculus extensor digitorum brevis is clinical and electrophysiological marker for L5/S1 radicular lesions. Med Arh. 2010; 64 (4): 223-224.

3. Sinanović O. Electrophysilogical characteristics and clinical significance of Martin-Gruber anastomosis. Clin Neurophysiol. 2011; 122: e1-e2.

4. Gutmann L. Important of anomalous innervations of the extremities. Muscle Nerve. 1993; 16: 339-347.

5. Sinanović O, Zukić S, Redžić L, Tinjić N, Baručija M, Galić G. Atypical carpal tunnel syndrome due to presence of MartinGruber anastomosis. Acta Med Sal. 2017; 6(1): 14-16.

6. Sinanović O. Neurophysiological and clinical aspects of varations in innervation of the upper and lower extremities. Neurol Croat. 2015; 64 (Suppl 2): 56-57. (Abstract of Invited Lecture)

7. Martin R. Talom Nervus alimanna Egenskaper I Maniskans Kropp. Las Salvius, 1763.

8. Gruber W. Ueber die Verbindung des Nervus medianus mit dem Nervus ulnaris am Unterame des Menschen um der Saugethiere. Arch Physiol. 1870; 37 (2): 501-522.

9. Wilbourn AJ, Lambert EH. The forearm median-to-ulnar nerve communication; electrodiagnostic aspects. Neurology. 1976; 26: 368 .

10. Felippe MM, Telles Fl, Soares ACL and Felippe FM. Anastomosis between median nerve and ulnar nerve in the forearm. J Morphol Sci. 2012; 29(1): 23-26.

11. Zukić S, Sinanović O, Tinjić N. Anastomosis between the ulnar and median nerves in the forearm: an electrophysiological study. Acta Med Sal. 2017; 46 (1): 1-3.

12. Kimura I, Ayyar DR, Lippmann SM. Electrophysiological verification of the ulnar to median nerve communications in the hand and forearm. Tohoku J Exp Med. 1983; 141: 269-274.

13. Sundaram SM, Sundar B, Arunkumar MJ. Marinacci communication: An electrophysiological study. Neurophysiology. 2003; 114: 2334-2337.

14. Roy J, Henry BM, Pekala PA, Vikse J, Saganiak K, Walocha JA, Tomaszewski KA. Median and ulnar nerve anastomoses in the upper limb: A meta analysis. Muscle Nerve. 2016; 54(1): 36-47.

15. Kimura J. Electrodiagnosis in diseases of nerve and muscle: Principles and Practice. 4th edition. Oxford University Press: New York, 2013.

16. Owsiak S, Kostera-Pruszczyk A, Rowinska-Maracinska K. Accessory deep peroneal nerve - a clinically significant anomaly? Neurol Neurochir Pol. 2008; 42(2): 112-115.

17. Crutchfield CA, Gutmann L. Hereditary aspects of accessory dep peroneal nerve. J Neurol Neurosurg Psyciatry. 1973; 36: 989-990.

18. Ubogu EE. Complete innervation of extensor digitorum brevis by accessory deep peroneal nerve. Neuromusc Disord. 2005; 15: $562-564$.
19. Kuruvilla A. Acesory deep peroneal nerve. Neurol India. 2004; 52 (1): 135-135.

20. Koo YS, Cho CC, Kim B-J. Pitfalls in using electrophysiological studies to diagnose neuromuscular disorders. J Clin Neurol. 2012; 8: 1-14.

21. Sinanović O, Zukić S, Šakić A, Muftić M. The accessory deep peroneal nerve and anterior tarsal tunnel syndrome: case report. Acta Myol. 2013; 32(2): 110-112.

22. Sinanović O, Zukić S, Gorinjac S, Babić S. Motor conduction velocity of ulnar nerve in Martin-Gruber anastomosis. Europ J Neurol, 2011; 18 (9): 165.

23. Cavalheiro CS, Filho MR, Pedro G, Caetano MF, Vieira LA, Caetano EB. Clinical repercussions of Marzin-Gruber anastomosis: anatomical study. Rev Bras Ortop. 2016; 51(2): 214-223.

24. Pastor JP, Uclés AR. Estudio electrofisiológico de la inervación anómala de la mano. Rev Neurol. 2001; 32(2): 112-118.

25. Smith JL, Siddiqui SA, Ebraheim NA. Comprehensive summary of anastomoses between the median and ulnar nerves in the forearm and hand. J Hand Microsurg. 2019; 11(1): 1-5.

26. Piza-Katze H. Familial occurence of Martin-Gruber anastomosis. Handchirurgie. 1976; 8(4): 215- 2016.

27. Crutcfield CA, Gutmann L. Hereditary aspects of median-ulnar nerve communications. J Neurol Neurosurg Psychiatry. 1980; 43 (1): 53-55.

28. Srinivasan R, Rhodes J. The median-ulnar anastomosis (MartinGruber) in normal and congenitally abnormal fetuses. Arch Neurol. 1981; 38 (7): 418-419.

29. Rodriguez-Niedenführ M, Vazquez T, Parkin I, LoganB, Sanudo JR.Martin-Gruber anastomosis revisited. Clin Anat. 2002, 15: 129-134.

30. Amoiridis $G$ and Vlachonikolis IG. Verification of the median -to- ulnar and ulnar - to - median nerve motor fibers anastomosis in the forearm: An electrophysiological study. Clin Neurophysiolog. 2003; 114: 95-98.

31. Saba EA. Electrophysioogical study of Martin-Gruber anastomosis in a sample of Egyotians. Egypt Rheumatol Rehabil. 2017; 44: 153-158.

32. Taams KO. Martin-Gruber connections in South Africa. An anatomical study. J Hand Surg Br. 1997; 22 (3):328-330.

33. Shu HS, Chantelot C, Oberlin C, Alnot JY, Shao H. MartinGruber communicating branch: anatomical and histological study. SurgRadiolAnat 199; 21 (2): 115-118.

34. Sarikcioglu L, Sindel M, Ozkayanek S, Aydin H. Median and ulnar nerve communication in the forearm: an anatomical and electrophysiological study. Med Sci.Monit 2003; 9 (9): 351356.

35. Claussen GC, Ahmad BK, Sunwood IN, Oh SJ. Combined motor and sensory median - ulnar anastomosis: Report of an electrophysiologically proven case. Muscle Nerve. 1996; 19: 231-233. 
36. Simonetti S. Electrophysiological study of forearm sensory fiber crossover in Martin-Gruber anastomosis. Muscle Nerve. 2001; 24: 380-386.

37. Diz-Díaz J, Gómez-Muñoz E, Sañudo J, Maranillo, E, PascualFont A, Vazquez T. Which is the function of a Martin-Gruber connection? Clinical Anatomy.2019; 32:501-508.

38. Sinanović O, Zukić S, Muftić M. Sensory fibers in Martin-Gruber anastomosis: an electrophysiological study. $3^{\text {rd }}$ Congress of the European Academy of Neurology, Amsterdam, June 24-27, 2017.

39. Riechers RG, Landau ME, Farber G, Campbell WW. Damage to sensory fibers in Martin-Gruber anomaly after biceps tendon repair. J Clin Neuromuscul Dis. 2005; 6 (4): 162-166.

40. Uchida Y, Sugioka Y. Electrodiagnosis of Martin-Gruber connection and its clinical importance in peripehral nerve surgery. J Hand Surg Am. 1992; 17 (1): 54-59.

41. Ray WZ, Mackinnon SE. Clinical outcomes following median to radial nerve transfers. J Hand Surg Am. 2011; 36 (2): 201 208.

42. Demircay E, Civelek E, Cansever T, Kabatess S, Yimaz C. Anatomic variations of the median nerve in the carpal tunnel: a brief review of the literature. Turk Neurosurg. 2011; 21 (3): 388-396.

43. Kate N, Teli C, Gajbhiye R, Ambareesha K, Suresh M. A study to analyze the prevalence of nervous anastomosis (MartinGruber) in medical students: Natl J Physiol Pharm Pharmacol. 2015; 5: 185-189.

44. Caetano EB, Viera LA, Caetano MF, Cavalheiro CS, Razuk M, Sabongi JJ. Intramuscular Martin-Gruber anastomosis. Acta Ortop Bras. 2016; 24 (2): 94-97.

45. Hopf HC. Forearm ulnar-to-median nerve anastomosis of sensory axons. Muscle Nerve. 1990; 13 (7): 654-656.

46. Resende LA, Adamo AS, Kimaid PA,Castro HA, Canheu AC, Schelp AO. Ulnar - to- median nerve anastomosis in the forearm. Review and report of 2 new cases. Electromyogr Clin Neurophysiol. 2000; 40(4): 253-255.

47. Brandsma JW, Birke JA, Sims DS Jr. The Martin-Gruber innervated hand. J Hand Surg [Am]. 1986; 11: 536-539.

48. Whitaker $\mathrm{CH}$, Felice KJ. Apparent conduction block in patients with ulnar neuropathy at the elbow and proximal Martin-Gruber anastomosis. Muscle Nerve. 2004; 30:808-811.

49. Dogan N, Uysal I, Seker M. The communications between the ulnar and median nerves in upper limb. J Neuroanat. 2009; 8(1): 15-19.

50. Scelsa SN. Ulnar-median and median - ulnar anastomoses in the forearm: a patient report. Elecrtomyogr Clin Neurophysiol. 2000; 40(5): 311-315.

51. Meenakshi-Sundaram S, Sundar B, Arunkumar MJ. Marinacci communication: an electrophysiological study. Clin Neurophysiol. 2003; 114: 2334-2337.
52. Masakado Y, Kawakami M, Suzuki K, Abe L, Ota T, Kimura A. Clinical neurophysiology in the dignosis of peroneal nerve palsy. Keio J Med. 2008; 57 (2): 84-89.

53. Tzika M, Paraskevas GK, Kitsoulis P. The accessory deep peroneal nerve: a review of the literature. Foot (Edinb). 2012; 22(3): 232-234.

54. Crutchfield CA, Gutmann L. Hereditary aspects of accessory dep peroneal nerve. J Neurol Neurosurg Psyciatry. 1973; 36: 989-990.

55. Ubogu EE. Complete innervation of extensor digitorum brevis by accessory deep peroneal nerve. Neuromusc Disord. 2005; 15: 562-564.

56. Kuruvilla A. Acesory deep peroneal nerve. Neurol India 2004; 52 (1): 135-135.Koo YS, Cho CC, Kim B-J. Pitfalls in using electrophysiological studies to diagnose neuromuscular disorders. J Clin Neurol. 2012; 8: 1-14.

57. Saba EK. Electrophysiological study of accessory deep peroneal nerve in a sample of Egyptian subjects. Egypt Rhematol Rehabil. 2019; 46: 251-256.

58. Budak F, Gönenc Z. Innervation anomalies in upper and lower extremities (an electrophysiological study). Electromyogr Clin Neurophysiol. 1999; 39:231-234.

59. Rayegani SM, Daneshtalab E, Bahrami MH, Eliaspour D, Raeissadat SA, Rezaei S, Babaee M. Prevalence of accessory deep peroneal nerve in referred patients to an electrodiagnostic medicine clinic. J Brachial Plex Peripher Nerve Inj. 2011; 6 (1):3.

60. Mathis S, Ciron J, du Boisguéheneuc F, Godenèche G, Hobeika L, Larrieu D, Neau JP. Study of accessory deep peroneal nerve motor conduction in a population of healthy subjects. Neurophysiol Clin. 2011; 41(1):29-33.

61. Sinanović O, Zukić S, Pirić N. Prevalence of the accessory deep peroneal nerve in patients refferred to an electromyoography lab. Europ J Neurol. 2014; 21 (Suppl 1): 495.

62. Sinanović O, Zukić S, Pirić N. Frequency of accessory deep peroneal nerve: electrophysiological study. Europ J Neurol. 2015; 22 (Suppl 1): 428.

63. Tomaszewski KA, Roy J, Vikse J, Pekala PA, Kopacz P, Henry BM. Prevalence of the accessory deep peroneal nerve: a cadaveric study and meta-analysis. Clin Neurol Neurosurg. 2016; 144:105-111.

64. Sinanović $\mathrm{O}$, Zukić S, Pirić N, Brkić H, Hodžić M, Hodžić R, Baručija M. Anterior tarsal tunnel syndrome with presence of accessory deep peroneal nerve: case report. J Neurol Neurol Sci Disord. 2015; 1(1): 15-16.

65. Phillips LH, Morgan RF: Tibial-peroneal anomalous innervation demonstrated by intraoperative nerve conduction studies. Muscle Nerve 1993; 16 (4): 414-417.

66. Weisz RR, Cox KJ: Posterior tibial-to-peroneal nerve crossover: an electromyographic study. Cincinnati, OH, Society of Neurosciences (10th annual meeting), 1980. 
67. Linden D, Berlit P. The intrinsic foot muscles are purely innervated by the tibial nerve (,all tibila" foot") - an unusual innervation anomaly. Muscle Nerve 1994; 17 (5): 560-561.

68. Glocker FX, Deuschl G, Lücking CH. Traumatic lesion on the common peroneal nerve with complete foot drop and preserved dorsiflexion of the toes-an innervation anomaly. Muscle Nerve 1995;18: 926.

69. Linden D. Traumatic lesion on the common peroneal nerve with complete foot drop and preserved dorsiflexion of the toes-an innervation anomaly [a reply]. Muscle Nerve 1995;18: 926-927.

70. Yamashita M, Mezaki T, Yamamoto T. "All tibial foot" with sensory crossover innervation between the tibial and deep peroneal nerves. J Neurol Neurosurg Psychiatry. 1998;65(05):798-799.

71. Swerdloff MA, Stewart D. Anomalous innervation to the extensor digitorum brevis. J Brachial Plex Peripher Nerve Inj 2019; 14 (1): 14-15.

ACKNOWLEDgeMENTS: None CONFLICT OF INTEREST: None CONTRIBUTION OF INDIVIDUAL AUTHORS:

Osman Sinanović: concept and design of article, literature searches, writing manuscript, approval of final version. Sanela Zukić: comments on the concept of article, literature searches, approval of the final version. 